Studia nad Autorytaryzmem i Totalitaryzmem 43, nr 3

Wrocław 2021

https://doi.org/10.19195/2300-7249.43.3.13

\author{
JOLANTA BEHR \\ ORCID: 0000-0002-2688-2836 \\ Uniwersytet Wrocławski \\ jolanta.behr2@uwr.edu.pl
}

\title{
Rola prawa działalności kulturalnej w indoktrynowaniu społeczeństwa w okresie Polskiej Rzeczypospolitej Ludowej — część II
}

Słowa kluczowe: prawo działalności kulturalnej, Polska Rzeczpospolita Ludowa, indoktrynacja, propaganda, cenzura, administracja państwowa, zadania i ustrój administracji państwowej, kultura.

\author{
THE ROLE OF THE LAW ON CULTURAL ACTIVITY \\ IN THE SOCIAL INDOCTRINATION \\ DURING THE POLISH PEOPLE'S REPUBLIC PERIOD. PART II
}

\begin{abstract}
The aim of the article is to establish the role of the law of cultural activity in the process of indoctrination of society in the period of the Polish People's Republic. The work will analyze the legal acts regulating the system and tasks of state entities involved in the promotion of ideas and views approved by the then authorities, primarily of a socialist nature.

It will be shown in the work that the law of cultural activity played an important role in indoctrinating society during the communist period. It actively supported state bodies, legitimizing their actions. The support was provided to a different extent and in various forms, both imperious and non-imperative. The general axiology of law included the values approved by the rulers, in the light of which legal provisions should be interpreted. The law also created an organized state administration apparatus whose task was to influence the society. A complex, multi-level system of state administration was created, the scope of which was to create a new reality and support the authorities and parties. Care was taken to ensure that the information provided to the public was 'properly' verified. Entities providing them were regulated, in various forms and scope. Actions in
\end{abstract}

* Pierwsza część zob. SNAT 43.2. 
this area were carefully planned and carried out, taking into account the orders of the party authorities subordinate to the authorities in Moscow. The minister for propaganda, organizing and coordinating the activities of state entities, functioned informally. The tasks and competences of state administration entities and bodies in the field of cultural activity were often constructed by law with the use of undefined concepts. This created a wide field of interpretation for the state administration body, which adjusted the meaning assigned to them to the current needs and directions of the policy pursued, thus extending the scope of its activities. In many cases, the provisions of acts and decrees defined tasks and competences in a concise manner, allowing them to be further specified or developed by the provisions of regulations. This created a lot of room for maneuver for the administration, which itself created the regulations on the basis of which it functioned. In practice, it often extended the scope of its activities, interfering in an unauthorized way in the area of human and civil rights and freedoms. All this, however, was legal — on the basis and within the limits of the law. Moreover, the law regulated the control and supervision of entities popularizing cultural activity, enabling wide-ranging censorship. The law also specified severe sanctions against entities not complying with the current policy of the rulers. They were regulated by acts of cultural activity and acts of criminal law. Moreover, internal law played an important role.

Keywords: law of cultural activity, Polish People's Republic, indoctrination, propaganda, censorship, state administration task and system of public administration, culture.

W pierwszej części pracy określono czynniki i podmioty mające wpływ na kształtowanie kierunków polityki w okresie PRL-u, opisano funkcje kultury w państwach o ustrojach niedemokratycznych, przeanalizowano podstawy prawne regulujące działalność organów i podmiotów państwowych, wykonujących zadania związane $\mathrm{z}$ organizowaniem, upowszechnianiem oraz sprawowaniem kontroli i nadzoru nad działalnością kulturalną w PRL-u. W tej części skoncentrowano się na przepisach prawa, na podstawie których funkcjonowały kolejne podmioty państwowe, oraz sformułowano wnioski miarodajne dla całego analizowanego obszaru.

Następnym podmiotem funkcjonującym początkowo na podstawie aktów normatywnych wydanych przed uchwaleniem Konstytucji PRL był Główny Urząd Kontroli Prasy, Publikacji i Widowisk, podlegający Prezesowi Rady Ministrów. Kierował nim dyrektor mianowany przez Radę Ministrów na wniosek Prezesa Rady Ministrów. Głównemu Urzędowi podlegały urzędy terenowe ${ }^{1}$.

Zakres zadań urzędu był początkowo ograniczony. Należało do niego sprawowanie nadzoru nad prasą, publikacjami i widowiskami w zakresie przewidzianym w przepisach szczególnych oraz sprawowanie kontroli rozpowszechniania wszelkiego rodzaju utworów za pomocą druku, obrazu i słowa. Celem kontroli było zapobieżenie sytuacjom ściśle określonym w dekrecie, w tym: godzeniu w ustrój państwa, ujawnianiu tajemnic państwowych oraz wprowadzaniu w błąd opinii publicznej ${ }^{2}$.

${ }^{1}$ Dekret z dnia 5 lipca 1946 r. o utworzeniu Głównego Urzędu Kontroli Prasy, Publikacji i Widowisk, Dz.U. Nr 34, poz. 210.

2 Ibidem. 
Z upływem czasu urząd zyskiwał na znaczeniu, a zakres jego działania zwiększano ${ }^{3}$. Obejmował on już między innymi: nadzór i kontrolę rozpowszechniania wszelkiego rodzaju utworów za pomocą druku, obrazu i żywego słowa oraz ogłoszeń, zawiadomień i plakatów, jak też innych form służących do utrwalania i przekazywania informacji. Należało do niego także udzielanie zezwoleń na wydawanie czasopism oraz podejmowanie określonych prawem czynności związanych z debitem komunikacyjnym. Wraz z organami terenowymi prowadził ponadto rejestrację zakładów zajmujących się szeroko pojętym drukiem. Przepisy prawa, na podstawie których funkcjonował, były sformułowane dość ogólnie 4 , a praktyka ich stosowania odbiegała od wymogów stawianych kontrolom. Ingerowano bowiem istotnie $\mathrm{w}$ funkcjonowanie podmiotów kontrolowanych. Wbrew ustawowemu określeniu był to zatem szeroko pojęty nadzór, a nie kontrola. Równolegle prowadzono nadzór prewencyjny, czyli taki, którego celem jest uniemożliwienie podjęcia niezgodnego $\mathrm{z}$ prawem działania. $\mathrm{W}$ jego ramach stosowano środki władcze, ingerując bezpośrednio w sferę praw i wolności — ingerowano w treść i formę dzieł twórców, które podlegały uprzedniemu zatwierdzeniu i dostosowaniu do potrzeb rządzących ${ }^{5}$.

Dokonując próby oceny pozycji urzędu, wskazuje się, że

choć pod względem formalnym cenzura decydowała o przyznawaniu zezwoleń (koncesji) na wydawanie tytułów prasowych, nadzorowała ich treść, druk i upowszechnianie, nie była jednak samodzielną instytucją. Zasady jej działania, zakres ingerencji, wykaz zakazanych nazwisk opracowywany były przede wszystkim przez komórki KC PZPR zajmujące się prasą i kulturą $^{6}$ oraz Ministerstwo Spraw Wewnętrznych i Ministerstwo Obrony Narodowej. Z wnioskami cenzorskimi występowały też inne ministerstwa, a nawet przedsiębiorstwa. Wnioski te musiały jednak uzyskać akceptację KC. Na praktykę tę, wykształconą już w pierwszych dniach funkcjonowania cenzury, wskazują liczne dokumenty archiwalne. [...] Instrukcje cenzorskie [...] dotyczyły praktycznie wszelkich aspektów funkcjonowania państwa. [...] Niemal każdemu wydarzeniu społeczno-politycznemu towarzyszyła szczegółowa instrukcja cenzorska ${ }^{7}$.

3 Zob. zarządzenie Prezesa Głównego Urzędu Kontroli Prasy, Publikacji i Widowisk z dnia 3 czerwca 1971 r. w sprawie rejestracji zakładów i urządzeń wytwarzających publikacje, ilustracje i pieczątki i zakładów sprzedaży matryc oraz w sprawie ewidencji wytwarzanych publikacji i sprzedawanych urządzeń, aparatów i matryc (M.P. nr 32, poz. 208); zarządzenie Prezesa Głównego Urzędu Kontroli Prasy, Publikacji i Widowisk z dnia 16 czerwca 1975 r. w sprawie trybu udzielania zgody na rozpowszechnianie informacji oraz rejestracji i kontroli zakładów, urządzeń i aparatów poligraficznych (M.P. nr 20, poz. 123).

${ }^{4}$ Zob. rozporządzenie Prezesa Rady Ministrów z dnia 21 marca 1970 r. w sprawie zakresu i trybu sprawowania nadzoru i kontroli przez organy prasy, publikacji i widowisk, Dz.U. $\mathrm{Nr} 6$, poz. 50, rozdz. VI.

5 Zob. rozporządzenie Prezesa Rady Ministrów z dnia 22 kwietnia 1975 r. w sprawie zakresu i trybu sprawowania nadzoru i kontroli przez Główny Urząd Kontroli Prasy, Publikacji i Widowisk, Dz.U. Nr 13, poz. $75, \S 4$.

6 Ważną rolę odgrywał w tym zakresie tak zwany sekretarz propagandy sukcesu Jerzy Łukaszewicz; zob. P. Donefner, Sekretarz propagandy sukcesu. Jerzy Łukaszewicz - przyczynek do biografii politycznej, „Polska 1944/45-1989. Studia i Materiały” 2019, nr 17, s. 297-311.

7 T. Mielczarek, Uwarunkowania prawne funkcjonowania cenzury w PRL, ,Rocznik Prasoznawczy" 2010, nr 4, s. 42. 
„Tradycję” indoktrynowania i cenzury kultywowano również w późniejszym czasie. Działania te były podejmowane na podstawie przepisów ustawy z dnia 31 lipca 1981 roku o kontroli publikacji i widowisk ${ }^{8}$. Artykuł 1 ust. 1-2 ustawy stanowił, że Polska Rzeczpospolita Ludowa zapewnia wolność słowa i druku w publikacjach i widowiskach. Ochrona i zapewnienie realizacji tej wolności było obowiązkiem organów i instytucji państwowych oraz organizacji politycznych i społecznych. Mimo formalnej deklaracji ustawa w kolejnych przepisach zakreślała granice, w ramach których wolność ta była realizowana. Formułowała obszerny katalog zachowań niedopuszczalnych ${ }^{9}$. Uznawała za nielegalne wszelkie przejawy nieposłuszeństwa względem rządzących i propagowanych przez nich idei, określając szeroko zakrojoną cenzurę ${ }^{10}$. Wyrażone $\mathrm{w}$ niej prawo wolności słowa i druku było zatem wyłącznie fasadowe. Na jego „straży” — w służbie państwu i partii - stały organy kontroli określone w ustawie, w tym okręgowe urzędy publikacji i widowisk oraz Główny Urząd Kontroli Publikacji i Widowisk. Ustawa zawierała ponadto przepisy karne. Osoby sprzeciwiające się władzy podlegały też karom określonym w przepisach odrębnych ${ }^{11}$. Niektóre z nich $-\mathrm{w}$ tym dotyczące propagandy wojennej - obowiązywały nadal wiele lat po formalnej zmianie ustroju. Kierunek ich wykładni jednak istotnie się zmieni1 ${ }^{12}$.

Wraz z wojskowym zamachem stanu, w którego wyniku wprowadzono stan wojenny ${ }^{13}$, wydano nowe regulacje prawne, a zakres stosowania dotychczasowych się zmienił. Zakazano między innymi zwoływania i odbywania wszelkiego rodzaju zgromadzeń oraz organizowania i przeprowadzania publicznych imprez artystycznych i rozrywkowych, z wyjątkiem przypadków, w których uzyskano uprzednie zezwolenie właściwego organu administracji państwowej. Odmowa

8 Dz.U. Nr 20, poz. 99.

${ }^{9}$ W jej zakresie znalazło się: godzenie w niepodległość lub integralność terytorialną PRL, nawoływanie do obalenia, lżenia, wyszydzania lub poniżania konstytucyjnego ustroju PRL, godzenie w konstytucyjne zasady polityki zagranicznej PRL oraz uprawianie propagandy wojennej.

${ }^{10}$ Ustawa odstępowała jednak od niektórych obszarów dotychczasowej cenzury, realizowanej w formie kontroli wstępnej.

11 Mowa przede wszystkim o: dekrecie z dnia 13 czerwca 1946 r. o przestępstwach szczególnie niebezpiecznych w okresie odbudowy Państwa (Dz.U. Nr 30 poz. 192 ze zm.) penalizującym między innymi: nawoływanie do czynów skierowanych przeciwko jedności sojuszniczej państwa polskiego z państwem sprzymierzonym; rozpowszechnianie fałszywych wiadomości, mogących wyrządzić szkodę interesom państwa polskiego bądź obniżyć powagę jego naczelnych organów oraz polegające na sporządzaniu, przechowywaniu lub przewożeniu pism, druków lub wizerunków, nawołujących do popełnienia zbrodni lub pochwalających zbrodnię, lub których treść ma pozostawać tajemnicą wobec władzy państwowej albo które zawierają fałszywe wiadomości, mogące wyrządzić istotną szkodę interesom państwa polskiego bądź obniżyć powagę jego naczelnych organów. Podobne regulacje $\mathrm{z}$ tego zakresu zawierały również: rozporządzenie Prezydenta Rzeczypospolitej z dnia 11 lipca 1932 r. Kodeks karny (Dz.U. Nr 60, poz. 571 ze zm.) oraz ustawa z dnia 19 kwietnia 1969 r. Kodeks karny (Dz.U. Nr 13, poz. 94).

12 Mowa o ustawie z dnia 29 grudnia 1950 r. o obronie pokoju (Dz.U. Nr 58, poz. 521), którą uchylono z dniem 1 września $1998 \mathrm{r}$.

13 A. Ajnenkiel, Konstytucje Polski w rozwoju dziejowym 1791-1997, Warszawa 2001, s. 335. 
jego wydania następowała, jeżeli zwołanie i odbycie zgromadzenia lub imprezy zagrażałoby bezpieczeństwu i obronności państwa. Określone w przepisie przesłanki odmowy były zwrotami niedookreślonymi. Interpretował je samodzielnie organ administracji państwowej, który mógł dostosowywać nadawane im znaczenie do bieżących potrzeb. Kompetencją Ministra Spraw Wewnętrznych było uregulowanie $\mathrm{w}$ drodze rozporządzenia ogólnych zasad wykonywania obowiązków związanych z tym obszarem oraz wprowadzenie całkowitych lub częściowych zwolnień od wymogu posiadania zezwolenia ${ }^{14}$. Przede wszystkim zwolnieniem objęto zgromadzenia zwoływane przez organy władzy i administracji państwowej oraz przez wymienione $\mathrm{w}$ akcie organizacje działające „w duchu socjalistycznym"15. Szczegółowo uregulowano ponadto liczne ograniczenia wykonywania praw związanych z działalnością kulturalną, określając surowe kary za ich naruszenie $^{16}$. Wraz z wprowadzeniem stanu wojennego dostęp do działalności kulturalnej znacznie ograniczono. Od tego czasu wiele środowisk artystycznych bojkotowało media państwowe. Część artystów udała się na emigrację, inni natomiast zaangażowali się $\mathrm{w}$ działania podziemne kultury protestu. Wspierał ich aktywnie Kościół katolicki ${ }^{17}$.

Mimo trudnej sytuacji panującej w kraju - krwawego tłumienia buntów, strajków i innych przejawów nieposłuszeństwa względem władz, a także licznych internowań ${ }^{18}$ - władze państwowe nadal przywiązywały szczególną uwagę do indoktrynowania społeczeństwa i prowadzenia działań propagandowych.

W 1982 roku utworzono Narodową Radę Kultury, będącą organem opiniodawczo-doradczym Rady Ministrów. W świetle prawa zmierzała ona do zespolenia działań i zapewnienia uczestnictwa kulturotwórczych sił narodu w kształtowaniu i realizacji zadań polityki kulturalnej. Jednym z głównych celów jej działania było umacnianie aktywnej roli kultury we wzbogacaniu życia duchowego narodu i jej wpływu na rozwój socjalistycznego społeczeństwa ${ }^{19}$.

Utworzono ponadto Fundusz Rozwoju Kultury, którego środkami dysponował na poziomie centralnym Minister Kultury i Sztuki, a na poziomie terenowym

14 Zob. dekret z dnia 12 grudnia 1981 r. o stanie wojennym (Dz.U. Nr 29, poz. 154); uchwała Rady Państwa z dnia 12 grudnia 1981 r. w sprawie wprowadzenia stanu wojennego ze względu na bezpieczeństwo państwa (Dz.U. Nr 29, poz. 155).

15 Rozporządzenie Ministra Spraw Wewnętrznych z dnia 30 stycznia 1982 r. w sprawie ogólnych zasad wykonywania obowiązków uzyskiwania zezwoleń na zwoływanie i odbywanie zgromadzeń, organizowanie publicznych imprez artystycznych, rozrywkowych i sportowych oraz przeprowadzanie zbiórek publicznych w czasie obowiązywania stanu wojennego, a także wyłączenia niektórych rodzajów zgromadzeń od obowiązku uzyskiwania zezwoleń, Dz.U. Nr 4, poz. 28.

16 Dekret o stanie wojennym, art. 17-19 oraz rozdział VI.

17 J. Grey, Trójmiejskie życie kulturalne w stanie wojennym i... ,,powojennym”, ,Dzieje Najnowsze" 49, 2017, nr 4, s. 237.

18 Rozporządzenie Rady Ministrów z dnia 12 grudnia 1981 r. w sprawie zasad postępowania w sprawach o internowanie obywateli polskich, Dz.U. Nr 29, poz. 159.

19 Nastąpiło to na podstawie ustawy z dnia 4 maja 1982 r. o Narodowej Radzie Kultury oraz o Funduszu Rozwoju Kultury, Dz.U. Nr 14, poz. 111. 
wojewódzkie, miejskie, miejsko-gminne i gminne rady narodowe. Środki funduszu przeznaczano przede wszystkim na finansowanie instytucji prowadzących działalność kulturalną oraz na finansowanie działań związanych z kulturą i sztuką, w tym podejmowanych poza granicami kraju ${ }^{20}$. Dostrzegano, że idea funkcjonowania funduszu - gwarantująca ochronę kultury przed ekonomizacją i komercjalizacją — była postępowa. Doceniano ją także poza granicami kraju. Niestety praktyka stosowania przepisów ustawy znacznie odbiegała od jej formalnych treści. Twierdzi się nawet, że nie zmieniła ona istotnie funkcjonowania instytucji prowadzących działalność kulturalną ${ }^{21}$.

Nieco uwspółcześnione podejście do działalności kulturalnej przyjmowała ustawa z dnia 26 kwietnia 1984 roku o upowszechnianiu kultury oraz o prawach i obowiązkach pracowników upowszechniania kultury ${ }^{22}$. Na niektórych jej przepisach wzorowano się, nawet projektując obowiązującą do dziś ustawę z dnia 25 października 1991 roku o organizowaniu i prowadzeniu działalności kulturalnej ${ }^{23}$. Była ona jednak ,przesiąknięta duchem socjalizmu”. Do głównych celów upowszechniania kultury zaliczała bowiem kształtowanie ideowych, moralnych i patriotycznych postaw obywateli, socjalistycznych stosunków i zasad współżycia społecznego. Upowszechnianie kultury uznano za część polityki społeczno-gospodarczej państwa, a zadania z nim związane określano w centralnych i terytorialnych planach społeczno-gospodarczych. Były one koordynowane na terenie całego kraju. Włączono w nie także przedsiębiorstwa państwowe i inne państwowe jednostki organizacyjne, spółdzielnie i ich związki, organizacje związkowe oraz inne organizacje zawodowe i społeczne. Ich działania były skierowane do pracowników i ich rodzin. Ustawa przewidywała też aktywny udział społecznego ruchu kulturalnego. Działania wszystkich jednostek upowszechniających kulturę objęto ochroną i pomocą państwa.

Stopniowo poszerzano zatem formalny zasięg indoktrynowania, tworząc złożony, wielopoziomowy system nadzorowany przez podmioty państwowe. Istotną rolę odgrywały w nim rady narodowe. Wynikało to także z przepisów Konstytucji PRL, które uznawały je za organy władzy państwowej w gminach, miastach, dzielnicach większych miast, powiatach i województwach (art. 34 i 37 Konstytucji PRL). Ich zadaniem było również kierowanie działalnością kulturalną w terenie.

Oprócz podmiotów, których obszar właściwości obejmował teren całego państwa, istotną rolę $\mathrm{w}$ indoktrynowaniu społeczeństwa odgrywały także podmioty funkcjonujące na poziomie lokalnym. Specyfika ich działania różniła się jednak od omówionych wcześniej. Na poziomie centralnym: ustalano plany, programy i kierunki polityki kulturalnej, wydawano przepisy prawa regulujące

20 Ibidem.

21 P. Płoski, Epizod konstruktywny. Fundusz Rozwoju Kultury 1983-1990, „Zarządzanie w Kulturze" 2020, nr 21, z. 1, s. 14-15.

22 Dz.U. Nr 26, poz. 129.

23 Tekst jedn. Dz.U. z 2020 r. poz. 194 ze zm. 
zasady działania i funkcjonowanie podmiotów świadczących usługi powszechnie dostępne $\mathrm{z}$ tego zakresu oraz regulujących działania twórców poza formalnymi strukturami. Wpływano na zakres dostępu, formę oraz treść udostępnianych dzieł. Decydowano ponadto o finansowaniu konkretnych podmiotów oraz sprawowaniu nad nimi kontroli i nadzoru. Na poziomie lokalnym wykonywano natomiast przepisy obowiązującego prawa, uwzględniając aktualną politykę rządu. Działania podejmowane na tym poziomie polegały przede wszystkim na bezpośrednim świadczeniu usług i stwarzaniu warunków do samoorganizowania się społeczeństwa „w duchu socjalizmu”. Istotną rolę odegrały tu instytucje upowszechniania kultury, które prowadziły także działania indoktrynacyjne.

Instytucjami w pełni uregulowanymi prawnie były biblioteki. Ich utworzeniu przyświecała - wyrażona w przepisach ustawy - ,idea służenia dobru ogólnemu" ${ }^{24}$. W praktyce pod pojęciem dobra ogólnego kryło się jednak dobro ludu pracującego, popierającego socjalizm. Inne światopoglądy odrzucano między innymi przez staranną selekcję posiadanych i udostępnianych zbiorów. Wycofano

m.in. książki autorów związanych z obozem piłsudczykowskim, szerzące kult marszałka, dzieła antykomunistyczne, przybliżające ideologię faszystowską, traktujące o wierze i Kościele. Centralny Zarząd Bibliotek wpływał na politykę gromadzenia nie tylko przez usuwanie książek „,szkodliwych”, lecz także tworzenie wykazów książek o „bezsprzecznej wartości”

$\mathrm{Z}$ upływem czasu - w wyniku zmian regulacji prawnych, stanowiących podstawę funkcjonowania bibliotek — stwierdzono wprost, że powinny one służyć socjalistycznemu wychowaniu społeczeństwa. W celu zagwarantowania właściwej realizacji tego założenia rozszerzono zakres sprawowanego nad nimi nadzoru. Bezpośredni nadzór nad bibliotekami publicznymi sprawowały odtąd organy prezydiów właściwych rad narodowych, a naczelny nadzór nad bibliotekami publicznymi sprawował Minister Kultury i Sztuki ${ }^{26}$. Kontynuowano ponadto zapoczątkowane wcześniej działania mające na celu skoordynowanie prac bibliotek szkolnych i publicznych tak, aby wspólnie służyły one „kształtowaniu naukowego światopoglądu młodego czytelnika i przyczyniały się do wychowywania go w duchu moralności socjalistycznej"27. Skoordynowanie działań w tym zakresie miało szczególne znaczenie dla władz, ułatwiało bowiem indoktrynowanie ucznia już we wczesnej fazie jego rozwoju, a staranny dobór udostępnianych treści wpływał na kształtowanie jego poglądów.

Działania organów centralnych były skierowane również względem bibliotekarzy. Od lat sześćdziesiątych zintensyfikowano wydawanie wiążących ich szczegółowych wytycznych do pracy $\mathrm{z}$ dziećmi oraz ramowych regulaminów

${ }^{24}$ Dekret z dnia 17 kwietnia 1946 r. o bibliotekach i opiece nad zbiorami bibliotecznymi, Dz.U. Nr 26, poz. 163, art. 1 i 2.

25 H. Langer, Biblioteki publiczne dla dzieci i młodzieży w PRL-u, [w:] Literatura dla dzieci młodzieży, red. K. Heska-Kwaśniewicz, K. Tałuć, Katowice 2014, t. 4, s. 231.

26 Ustawa z dnia 9 kwietnia 1968 r. o bibliotekach, Dz.U. Nr 12, poz. 63, art. 24.

27 H. Langer, op. cit., s. 236. 
konkursów, organizowanych przez biblioteki. Akty te miały charakter wewnętrznie obowiązujący i wpływały na pozycję prawną użytkowników bibliotek. Kształtowanie „nowego pokolenia” uznano za działanie priorytetowe. Przywiązywano do niego większą wagę niż do określania regulacji o charakterze ustrojowoprawnym lub technicznym, związanym z funkcjonowaniem bibliotek ${ }^{28}$.

Kolejnymi instytucjami upowszechniania kultury, w pełni zdefiniowanymi prawnie, były muzea. Celem ich działania było społecznie celowe wykorzystanie i udostępnianie dóbr kultury oraz ich ochrona. Dobra kultury uznawano za „czynny składnik współczesnego społeczeństwa socjalistycznego”. Szczegółowe przepisy prawa regulujące funkcjonowanie muzeów nie nawiązywały zasadniczo do indoktrynowania. Zastosowanie w tym zakresie znajdowały jednak, opisane wcześniej, przepisy ogólne dotyczące działalności kulturalnej. Kierunek działania muzeów wyznaczał Minister Kultury i Sztuki. Sprawował on także nad nimi naczelny nadzór oraz je finansował. Dotacji z budżetu państwa udzielał naczelny organ wskazany przez Prezesa Rady Ministrów ${ }^{29}$. Umożliwiało to wywieranie wpływu na tematykę i rodzaj upowszechnianych dzieł.

Pozostałe instytucje upowszechniania kultury prowadziły działalność kulturalną na podstawie opisanych już przepisów ogólnych. W swoich działaniach były one ponadto obowiązane kierować się przepisami aktów prawa wewnętrznie obowiązującego, wydawanymi przez organy państwowe. Należały do nich przede wszystkim instrukcje, zarządzenia, wytyczne i okólniki, regulujące tryb organizowania wydarzeń kulturalnych, ich tematykę, sposób interpretowania określonych wydarzeń oraz kwestie ideologicznie „niepoprawne”, których należało unikać ${ }^{30}$.

\section{Wnioski}

Przeprowadzone analizy wskazują, że prawo działalności kulturalnej odgrywało istotną rolę w indoktrynowaniu społeczeństwa w okresie PRL-u. Wspierało aktywnie organy państwowe, legitymując podejmowane przez nie działania. Wsparcie następowało w różnym zakresie i formach, zarówno władczych, jak i niewładczych.

W ramach ogólnej aksjologii prawa ujęto wartości aprobowane przez rządzących. Wyeksponowanie ich w akcie najwyższej rangi, którym była Konstytucja PRL, wpływało na cały system prawa. Wykładnia wszystkich przepisów prawa musiała być odtąd dokonywana „w duchu” tych właśnie wartości. Jeśli rezultaty

28 Ibidem, s. 232.

${ }^{29}$ Uchwała nr 190 Rady Ministrów z dnia 14 marca 1953 r. w sprawie zasad i trybu udzielania z budżetu Państwa dotacji dla instytucji, organizacji oraz stowarzyszeń społecznych i kulturalno-oświatowych, M.P. nr 29, poz. 356, § 3.

30 A. Leśniewski, Modele polityki kulturalnej państwa polskiego 1944-2015, Poznań 2017, s. 101. 
wykładni były niejednoznaczne, należało wybrać rozwiązanie uwzględniające w większym stopniu wartości i idee socjalistyczne.

Prawo tworzyło ponadto zorganizowany aparat administracji państwowej, którego jednym z zadań było wpływanie na społeczeństwo. Jego skutkiem miała być - ukierunkowana przez władze publiczne i partię rządzącą — zmiana sposobu myślenia i postrzegania rzeczywistości oraz wykształcenie postawy uległości względem władz.

Przepisy prawa ułatwiające indoktrynowanie dotyczyły przede wszystkim działalności kulturalnej. Rządzący mieli bowiem świadomość tego, że kultura jest nośnikiem idei i poglądów, przekazującym określony sposób myślenia i interpretowania faktów. Uczyniono ją więc istotnym narzędziem w indoktrynowaniu społeczeństwa. Oprócz organów administracji państwowej - realizujących typowe zadania związane $\mathrm{z}$ administrowaniem - utworzono równolegle złożony, wielopoziomowy system administracji państwowej, w której zakresie działania mieściło się kreowanie nowej rzeczywistości i wspieranie władz. Jego zadaniem było utrwalenie w świadomości członków społeczeństwa wizerunku władzy przyjaznej obywatelom i dążącej do zaspokojenia ich potrzeb oraz wyeliminowanie wszelkich przeciwnych światopoglądów.

Działania organów administracji państwowej dotyczyły wielu obszarów funkcjonowania społeczeństwa. Były przede wszystkim zorientowane na zorganizowane formy upowszechniania działalności kulturalnej. Prowadzono je jednak również w innych obszarach. Dbano, aby przekazywane społeczeństwu informacje były „odpowiednio” weryfikowane. Regulowały podmioty je udostępniające, w różnych formach i zakresie - od decydowania o rodzaju książek wypożyczanych przez biblioteki, przez cenzurowanie ogłoszeń, weryfikowanie poprawności politycznej prób generalnych widowisk teatralnych aż po władcze oddziaływanie na dopuszczenie „odpowiednich” osób do wykonywania projekcji filmów. Działania $\mathrm{z}$ tego zakresu były starannie zaplanowane $\mathrm{i}$ wykonywane, $\mathrm{z}$ uwzględnieniem szczegółowych poleceń władz partyjnych podległych władzom w Moskwie. $\mathrm{W}$ pewnym czasie dostrzegano nawet funkcjonującego nieformalnie ministra ds. propagandy, organizującego i koordynującego działania podmiotów państwowych. Sprawnemu koordynowaniu w tym okresie sprzyjała zasada centralizacji, na podstawie której skonstruowano aparat administracji państwowej.

Jeśli idzie o zadania i kompetencje podmiotów i organów administracji państwowej, to prawo konstruowało je często z zastosowaniem pojęć niedookreślonych, sformułowanych w sposób ogólny i niemający jednoznacznie określonych desygnatów. Tym samym organ administracji państwowej miał rozległe możliwości interpretacyjne, dostosowując nadawane im znaczenie do bieżących potrzeb i kierunków prowadzonej polityki i tak zwiększając zakres swojego działania. W wielu przypadkach przepisy ustaw i dekretów określały zadania i kompetencje w sposób zwięzły, dopuszczając ich dookreślenie lub rozwinięcie przepisami rozporządzeń. Stwarzało to szerokie pole manewru dla administracji, tworzącej 
przepisy, na podstawie których później funkcjonowała. W praktyce rozszerzała często zakres swojego działania, ingerując w sposób nieuprawniony w obszar praw i wolności człowieka i obywatela. Wszystko to następowało jednak legalnie - na podstawie i w granicach prawa.

W taki też sposób prowadzono kontrolę i nadzór nad podmiotami upowszechniającymi działalność kulturalną. W obszarze weryfikowania prawidłowości podejmowanych przez nie działań prowadzono szeroko zakrojoną cenzurę, skutecznie selekcjonując udostępniane treści i wpływając na formę ich przekazu.

Równolegle do tych działań prawo określało dotkliwe sankcje względem podmiotów niepodporządkowujących się kierunkom bieżącej polityki rządzących. Wynikały one zarówno z aktów regulujących działalność kulturalną, jak i aktów z zakresu prawa karnego.

Oddziaływanie w tym obszarze następowało także na podstawie przepisów prawa wewnętrznie obowiązującego. Obowiązywały między innymi liczne instrukcje, zalecenia oraz wytyczne wiążące pracowników administracji i regulujące podejmowane przez nich działania, także te, których adresatami były podmioty znajdujące się poza strukturą administracji. Uwzględniały one kierunki polityki partii i władzy.

Odformalizowany, lecz pośredni wpływ na ten obszar miały natomiast procedury wyłonienia piastunów organów administracji państwowej. Osoby, którym powierzano pełnienie tych funkcji, były odpowiednio weryfikowane pod kątem prowadzonej działalności i głoszonych poglądów.

Ostatnim przykładem określonego prawnie, pośredniego oddziaływania na działalność kulturalną było natomiast finansowanie. Skuteczne upowszechnianie kultury nie było bowiem możliwe bez wystarczających środków finansowych. Ich rozdysponowywanie przez podmioty państwowe w tym okresie następowało z uwzględnieniem „odpowiedniego" dla władz kryterium.

\section{Bibliografia}

Ajnenkiel A., Konstytucje Polski w rozwoju dziejowym 1791-1997, Warszawa 2001.

Donefner P., Sekretarz propagandy sukcesu. Jerzy Łukaszewicz - przyczynek do biografii politycznej, „Polska 1944/45-1989. Studia i Materiały” 2019, nr 17.

Grey J., Trójmiejskie życie kulturalne w stanie wojennym i... „powojennym”, „Dzieje Najnowsze" 49, 2017, $\mathrm{nr} 4$.

Langer H., Biblioteki publiczne dla dzieci i młodzieży w PRL-u, [w:] Literatura dla dzieci młodzieży, t. 4, red. K. Heska-Kwaśniewicz, K. Tałuć, Katowice 2014.

Leśniewski A., Modele polityki kulturalnej państwa polskiego 1944-2015, Poznań 2017.

Mielczarek T., Uwarunkowania prawne funkcjonowania cenzury w PRL, „Rocznik Prasoznawczy” 2010, $\mathrm{nr} 4$.

Płoski P., Epizod konstruktywny. Fundusz Rozwoju Kultury 1983-1990, „Zarządzanie w Kulturze” 2020, nr 21, z. 1. 


\section{Wykaz źródeł prawa}

Dekret z dnia 17 kwietnia 1946 r. o bibliotekach i opiece nad zbiorami bibliotecznymi, Dz.U. Nr 26, poz. 163.

Dekret z dnia 13 czerwca 1946 r. o przestępstwach szczególnie niebezpiecznych w okresie odbudowy Państwa, Dz.U. Nr 30 poz. 192 ze zm.

Dekret z dnia 5 lipca 1946 r. o utworzeniu Głównego Urzędu Kontroli Prasy, Publikacji i Widowisk, Dz.U. Nr 34, poz. 210.

Dekret z dnia 12 grudnia 1981 r. o stanie wojennym, Dz.U. Nr 29, poz. 154.

Rozporządzenie Prezydenta Rzeczypospolitej z dnia 11 lipca 1932 r. Kodeks karny, Dz.U. Nr 60, poz. $571 \mathrm{ze} z \mathrm{zm}$.

Rozporządzenie Ministra Spraw Wewnętrznych z dnia 30 stycznia 1982 r. w sprawie ogólnych zasad wykonywania obowiązków, uzyskiwania zezwoleń na zwoływanie i odbywanie zgromadzeń, organizowanie publicznych imprez artystycznych, rozrywkowych i sportowych oraz przeprowadzanie zbiórek publicznych w czasie obowiązywania stanu wojennego, a także wyłączenia niektórych rodzajów zgromadzeń od obowiązku uzyskiwania zezwoleń, Dz.U. Nr 4, poz. 28.

Rozporządzenie Prezesa Rady Ministrów z dnia 21 marca 1970 r. w sprawie zakresu i trybu sprawowania nadzoru i kontroli przez organy prasy, publikacji i widowisk, Dz.U. Nr 6, poz. 50.

Rozporządzenie Prezesa Rady Ministrów z dnia 22 kwietnia 1975 r. w sprawie zakresu i trybu sprawowania nadzoru i kontroli przez Główny Urząd Kontroli Prasy, Publikacji i Widowisk, Dz.U. Nr 13, poz. 75.

Rozporządzenie Rady Ministrów z dnia 12 grudnia 1981 r. w sprawie zasad postępowania w sprawach o internowanie obywateli polskich, Dz.U. Nr 29, poz. 159.

Uchwała nr 190 Rady Ministrów z dnia 14 marca 1953 r. w sprawie zasad i trybu udzielania z budżetu Państwa dotacji dla instytucji, organizacji oraz stowarzyszeń społecznych i kulturalno-oświatowych, M.P. Nr 29, poz. 356.

Uchwała Rady Państwa z dnia 12 grudnia 1981 r. w sprawie wprowadzenia stanu wojennego ze względu na bezpieczeństwo państwa, Dz.U. Nr 29, poz. 155.

Ustawa z dnia 29 grudnia 1950 r. o obronie pokoju, Dz.U. Nr 58, poz. 521.

Ustawa z dnia 9 kwietnia 1968 r. o bibliotekach, Dz.U. Nr 12, poz. 63.

Ustawa z dnia 19 kwietnia 1969 r. Kodeks karny, Dz.U. Nr 13, poz. 94.

Ustawa z dnia 31 lipca 1981 r. o kontroli publikacji i widowisk, Dz.U. Nr 20, poz. 99.

Ustawa z dnia 4 maja 1982 r. o Narodowej Radzie Kultury oraz o Funduszu Rozwoju Kultury, Dz.U. Nr 14, poz. 111.

Ustawa z dnia 26 kwietnia 1984 r. o upowszechnianiu kultury oraz o prawach i obowiązkach pracowników upowszechniania kultury, Dz.U. Nr 26, poz. 129.

Ustawa z dnia 25 października 1991 r. o organizowaniu i prowadzeniu działalności kulturalnej, tekst jedn. Dz.U. z 2020 r. poz. 194 ze zm.

Zarządzenie Prezesa Głównego Urzędu Kontroli Prasy, Publikacji i Widowisk z dnia 3 czerwca 1971 r. w sprawie rejestracji zakładów i urządzeń wytwarzających publikacje, ilustracje i pieczątki i zakładów sprzedaży matryc oraz w sprawie ewidencji wytwarzanych publikacji i sprzedawanych urządzeń, aparatów i matryc, M.P. nr 32, poz. 208.

Zarządzenie Prezesa Głównego Urzędu Kontroli Prasy, Publikacji i Widowisk z dnia 16 czerwca 1975 r. w sprawie trybu udzielania zgody na rozpowszechnianie informacji oraz rejestracji i kontroli zakładów, urządzeń i aparatów poligraficznych, M.P. nr 20, poz. 123. 